\title{
Usefulness of plasma D-dimer level for monitoring development of distant organ metastasis in colorectal cancer patients after curative resection [Corrigendum]
}

\author{
GuoY,Chen F, Cui W. Cancer Manag Res. 2018;10:4203-4216.
}

On page 4211, "Acknowledgments" section, "the National Natural Science Foundation of China (Grant No 81778272)" should read "the National Natural Science Foundation of China (Grant No 81772272)".

\section{Publish your work in this journal}

Cancer Management and Research is an international, peer-reviewed open access journal focusing on cancer research and the optimal use of preventative and integrated treatment interventions to achieve improved outcomes, enhanced survival and quality of life for the cancer patient. The manuscript management system is completely online and includes a very quick and fair peer-review system, which is all easy to use. Visit http://www.dovepress.com/testimonials.php to read real quotes from published authors. 